\title{
Some New World Lessons for the Old World
}

\author{
Akhil Reed Amari
}

... [Y]ou are called upon to deliberate on a new Constitution for the United States of America. The subject speaks its own importance; comprehending in its consequences nothing less than ... the fate of an empire in many respects the most interesting in the world. It has been frequently remarked that it seems to have been reserved to the people of this country, by their conduct and example, to decide the important question, whether societies of men are really capable or not of establishing good government from reflection and choice, or whether they are forever destined to depend for their political constitutions on accident and force.... [A] wrong election of the part we shall act may, in this view, deserve to be considered as the general misfortune of mankind. ${ }^{1}$

So begins the extraordinary set of essays now known as The Federalist Papers. Even as Publius begins his address to fellow Americans, he reminds them that the world is watching. The success or failure of the American experiment in self-rule, says Publius, might well determine the fate of republican government for all humanity. In this belief Publius was hardly unique. Indeed, he notes that the importance of the American experiment for the rest of the planet "has been frequently remarked." Even in 1787, this idea was very old. We need only recall grade-school civics: the Puritans who began arriving in America in the early seventeenth century sought to establish a New England that would serve as a model not just for the Old England, but for the entire Old World.

Nor was this idea limited to the generations that founded the colonies and the Constitution. Consider, for example, the words of Abraham Lincoln during the American Civil War. In his second Annual Message to Congress in 1862, Lincoln self-consciously defined the meaning of America's domestic schism in global terms:

\footnotetext{
$\dagger$ Professor of Law, Yale University.

I Federalist 1 (Hamilton), in Clinton Rossiter, ed, The Federalist Papers 33 (New Am Library, 1961).
} 
"We say we are for the Union. The world will not forget that we say this. . . . We shall nobly save, or meanly lose, the last, best hope of earth." 2 To the same effect was his Gettysburg Address: "Now we are engaged in a great civil war, testing whether [our] nation or any nation ... conceived [in liberty and] dedicated [to equality] can long endure. . . . The world [cannot] forget what [American soldiers] did here [so] that government of the people, by the people, for the people, shall not perish from the earth."3

In this essay, I propose that we take Publius and Lincoln at their word, and consider some lessons that the New World experiment in republican government can offer to an Old World in the pangs of political rebirth. I do not mean to suggest that the American tradition merits full-fledged replication abroad. Nor is such replication likely; the draft constitutions of most Eastern European countries rightly reflect the countries' own traditions, and those of Western Europe, at least as much as they reflect the American experience. I simply suggest that the American experience does have some valuable lessons to offer as Eastern Europe goes through the process of constitution-making.

I despair of any hope of comprehensiveness-the topic is far too vast, and my knowledge far too small. I therefore propose to limit my remarks to three areas in which the American Constitution is generally considered to have made distinctive contributions and to have enjoyed considerable success. I shall examine the ways in which the United States Constitution has established an extended republic based on democratic principles; a unique system of power-sharing between center and periphery (federalism); and civilian supremacy over the military. In the course of examining these three interrelated-or so I shall argue-topics, I shall place considerable emphasis on the early American experience for two reasons. First, although late twentieth-century Eastern Europeans can learn much from their contemporary American counterparts, and vice versa, the effort now underway in Eastern Europe to found the right traditions and frame the right legal structures raises distinctive issues of founding and framing, issues importantly illuminated by America's early Founders and Framers. Second, several of the lessons from the early American experience may prove relevant today at home as well as abroad-and yet are in danger of being forgotten on both sides of the Atlantic.

${ }^{2}$ Roy P. Basler, ed, 5 The Collected Works of Abraham Lincoln 537 (Rutgers, 1953).

37 id at 23. 
Although my discussion shall make regular reference to the text of our constitution, we must remember that the document that emerges at the end of a constitution-making process is just that-a piece of paper. It cannot guarantee liberty and security unless it is first designed with a keen awareness of the likely threats to these two aims, and then executed and enforced over a period of many years by individuals who scrupulously respect its architecture and purposes. As we shall see, geography and history forge constitutions every bit as much as the framers who put pen to paper and the ratifiers who formally turn words into law.

\section{An Extended Democratic Republic}

The American Constitution was absolutely novel in attempting to extend republican government over an expansive geographic area-truly, across a continent. ${ }^{4}$ Previous historical examples of self-governing societies were much more geographically limited, the classic examples being the early Greek city-states and pre-imperial Rome. Orthodox political theorists in the 1780 s, represented in America by the Anti-Federalists, argued that this was no accident. Democracy, they argued, was inherently incapable of being extended across a vast realm. ${ }^{5}$

Most constitutional scholars today are aware of this controversy. They are also aware of two of Publius's arguments against Anti-Federalist orthodoxy. First, Hamilton argued in Federalist 9 that the work of "the celebrated Montesquieu"s actually supported the Anti-Federalists far less than they supposed, for Montesquieu had suggested that a "confederate republic" could avoid some of the geographic limitations inherent in simple democracies. ${ }^{7}$ Second, and more familiar today, Madison built on the ideas of David Hume $^{8}$ by arguing in Federalist 10 that an extended republic was

- Not all Framers envisioned that their new nation would stretch to the Pacific; yet virtually all did foresee that the nation would grow westward to include, for example, the old Northwest Territory. The Constitution provided for the admission of new states, but clearly suggested that new states would develop through the addition of new territory rather than through merger or division of existing states, which Article IV forbids without the consent of the states concerned. Thus, the clause about new states was immediately followed by language discussing territories. US Const, Art IV, $\S 3$.

- For a representative sample of Anti-Federalist thought, see Cecilia Kenyon, ed, The Antifederalists (Bobbs-Merrill, 1966).

- The phrase is Madison's. Federalist 47 (Madison), in Rossiter, ed, The Federalist Papers at 301 (cited in note 1 ).

7 Federalist 9 (Hamilton), in id at 74.

- See Douglass Adair, Fame and the Founding Fathers 93-106 (Norton, 1974); Gary Wills, Explaining America: The Federalist 223-30 (Doubleday, 1981). 
more likely to control factionalism, the characteristic vice of selfgoverning societies. ${ }^{9}$

\section{A. Publius's Forgotten Vision}

What is striking, however, is that scholars today are generally unaware of Publius's earlier and most basic argument against the Anti-Federalists, which I call the "geostrategic" argument. The entire introductory section of The Federalist Papers was designed to address head-on the Anti-Federalist orthodoxy about geography and democracy; Federalists 9 and 10 came onto the scene relatively late. What was Publius's argument for Union before he finally reached 9 and 10? Distilling the analysis of Federalists 4 through 8 , I would paraphrase ${ }^{10}$ the argument as follows:

Rampant despotism reigns over almost all of the European continent in 1787, yet England is relatively free. ${ }^{11}$ Why? In part, no doubt, because of the magnificence of the common law, and the glorious English Constitution, but also because of England's unique "insular" condition. ${ }^{12}$ As an island, she is protected from the military depredations of her neighbors by the English Channel. So long as Britannia maintains a strong navy and rules the waves (remember 1588), she need not overly concern herself with the horrible prospect of invasion. ${ }^{13}$ Navies, moreover, are relatively defensive creatures that cannot easily be turned upon Englishmen to impose domestic tyranny. ${ }^{14}$ Large standing armies are another story-the story, indeed, of tyranny. Yet regimes on the continent of Europe may well require such armies to defend land borders against invasion. ${ }^{15}$ Tragically, land borders often lead to a race to the 1).

9 Federalist 10 (Madison), in Rossiter, ed, The Federalist Papers at 82-83 (cited in note

10 I have chosen to paraphrase here in order to save the reader's time. I of course urge all interested readers to read Federalists 4 through 8-especially 8-for themselves. To make things easier, I have liberally seasoned my paraphrase with page citations.

${ }^{11}$ See especially Federalist 8 (Hamilton), in Rossiter, ed, The Federalist Papers at 6671 (cited in note 1 ).

12 Id at 70.

1s Id ("An insular situation, and a powerful marine, guarding [Great Britain] against the possibility of foreign invasion, supersede the necessity of a numerous army within the kingdom.").

${ }^{24}$ Id ("The military state becomes elevated above the civil."); see also id at 66-68 (linking "standing armies" and loss of "liberty").

${ }^{15}$ See generally Federalist 8 (Hamilton); see also Federalist 5 (Jay), in id at 51 ("bordering nations [are] always ... e either involved in disputes and war, or live in the constant apprehension of them") (emphasis in original). 
bottom in which a single ambitious regime arming itself for military adventurism forces each of its neighbors to build up its army to deter and (if necessary) repel invasion. ${ }^{16}$

But armies beget strong executives to lead them, and the combination begets domestic tyranny. Unlike navies, armies can easily be used not just to thwart invaders, but to crush domestic liberty. ${ }^{17}$ The task for Americans, then, is to structure our affairs to avoid the general fate of the European Continent, ${ }^{18}$ as the English have done with a God-given moat (the Channel) and the Swiss with a God-given rampart (the Great Wall of the Alps). ${ }^{19}$.

The existing Articles of Confederation have proved utterly unworkable; the existing confederation is de facto dissolved. ${ }^{20}$ Suppose we were to replace the Confederation with thirteen separate nations, each with land borders with its neighbors, free to arm itself without limit. Each nation-state would undoubtedly raise an army, ostensibly to protect itself against Indians or British, French, or Spanish outposts, but also to intimidate its neighbors. We would then recreate continental Europe and the near-universal tyranny that characterizes that continent. ${ }^{21}$ To opt instead for a system of three or four smaller confederacies (perhaps a Northern, a Southern, and one or two mid-Atlantic leagues) would not be much better, ${ }^{22}$ especially given the tremendous conflict that will predictably arise concerning control of the West. ${ }^{23}$ If, however, an unum can be forged from pluribus, America will resemble England. ${ }^{24}$ The three-thousand mile wide Atlantic ocean will be America's moat, for it will protect her against replication of, and subjugation by, the militarism of the European Continental powers. We can rely primarily on a modestly sized navy.

\footnotetext{
16 Federalist 8 (Hamilton), in id at 68.

17 Id.

18 Id at 70-71.

19 Federalist 19 (Madison and Hamilton), in id at 133 (Swiss "are kept together by the peculiarity of their topographical position").

${ }^{20}$ Federalist 1 (Hamilton), in id at 37; Federalist 8 (Hamilton), in id at 71.

"See generally Federalist 8 (Hamilton).

22 Federalist 2 (Jay), in id at 37-38, 41; Federalist 3 (Jay), in id at 43; Federalist 4 (Jay), in id at 48-49; Federalist 5 (Jay), in id at 51-53; Federalist 8 (Hamilton), in id at 71.

2s Federalist 7 (Hamilton), in id at 60-62 ("Territorial disputes have at all times been found one of the most fertile sources of hostility among nations. ... This cause would exist among us in full force. We have a vast tract of unsettled territory.").

34 Federalist 5 (Jay), in id at 50-51; see generally Federalist 8 (Hamilton).
} 
To be sure, the new nation might require a very small army to fortify the South and West against Indians, and the North against Canada, but none of these land-bordering regimes can truly threaten the united states, or provide the president a pretext to create a dangerously large standing army. ${ }^{25}$ Unless, of course, one of the land-bordering regimes received strong support from the Old Powers in Europe, whom Americans must discourage from strengthening their footholds in the New World. ${ }^{26}$ And once again, united states would be more likely to discourage European adventurism, disabling the Old Powers from playing state off against state in classic divide-and-conquer fashion. ${ }^{27}$

Here, then, is the first and most elaborate of Publius's three main responses to the Anti-Federalists. It is also the response in which the triumvirate sharing the mask of Publius-John Jay, Alexander Hamilton, and James Madison-most clearly spoke with one voice. Hamilton, for example, had expressed real doubts in his notes at the Philadelphia convention about the line of argument that eventually became Madison's Federalist $10,{ }^{28}$ whereas Madison's June 29 speech at Philadelphia almost perfectly anticipated Jay's and Hamilton's geostrategic argument for the Union in Federalists 4 through $8 .^{29}$ Madison returned to this theme in Federalist 41 , where he carefully cross-referenced and elaborated the geostrategic argument of the early Federalist Papers. ${ }^{30}$

Others shared Publius's geostrategic vision. The geostrategic argument was a dominant strand in the pro-ratification speeches of James Wilson, perhaps the most farsighted Federalist theorist. ${ }^{31}$ So too, Benjamin Franklin, the grand old man of the Philadelphia convention, invoked the vision in private correspondence shortly after the convention adjourned..$^{32}$ Nor is there any doubt that George Washington, the Federalists' political standard-bearer,

\footnotetext{
${ }^{25}$ Federalist 4 (Jay), in id at 49.

${ }^{28}$ Id; Federalist 5 (Jay), in id at 53; Federalist 7. (Hamilton), in id at 65-66.

${ }^{27}$ See sources cited in note 26.

${ }^{28}$ Max Farrand, ed, 1 The Records of the Federal Convention of 1787 145-47, 308-09 (Yale, rev ed 1937).

${ }^{28}$ Id at $463-65$.

so Federalist 41 (Madison), in Rossiter, ed, The Federalist Papers at 258-61 (cited in note 1).

si See Jonathan Elliot, The Debates in the Several State Conventions on the Adoption of the Federal Constitution 527-29 (Taylor \& Maury, 1854) (remarks of James Wilson at Pennsylvania ratifying convention in 1787).

${ }^{32}$ Charles Warren, The Supreme Court and the Sovereign States 145-46 n 41 (Princeton, 1924).
} 
shared this vision. As a surveyor and general, Washington instinctively grasped geography and military strategy much better than he did abstruse debates about Montesquieu and Hume. Indeed, Washington devoted major portions of his Presidential Farewell Address (composed with help from each member of the Publian triumvirate) to the implications of Publian geostrategy. ${ }^{33}$

\section{B. The Early American Experience}

The geostrategic argument provides a better window onto the American political and legal landscape from 1788 to 1865 than does the now-canonical Federalist 10. If, as Federalist 10 asserts, states were indeed widely understood in 1789 as more threatening to liberty than was the national government, then surely much of the original Bill of Rights should have applied against the states. So Madison urged in the first Congress, only to see the Senate eliminate all of his proposed restrictions on state governments. ${ }^{34}$ The Bill of Rights restricted only the federal government, the government with control of the ever-dangerous army, as Chief Justice John Marshall made clear in Barron v Baltimore. ${ }^{35}$ And lest there be any doubt, the Second and Third Amendments confirmed American jealousy against the $\operatorname{army}^{36}$ while saying nothing about the navy-precisely in keeping with Publius's geostrategic argument. ${ }^{37}$

President Jefferson also offered a vision of the Union far closer to the geostrategic one than to that of Federalist 10. He regularly described the raison d'etre of the federal government as defense and international affairs, utterly ignoring Federalist 10's argument about the need to protect individuals from tyrannical factionalism 1967).

${ }^{33}$ See Richard B. Morris, ed, Great Presidential Decisions 29-47 (Lippincott, rev ed

[E]very part of our country ... must derive from union an exemption from those broils and wars between themselves which so frequently afflict neighboring countries not tied together by the same governments .... [L]ikewise, they will avoid the necessity of those overgrown military establishments which, under any form of government, are inauspicious to liberty, and which are to be regarded as particularly hostile to republican liberty.

Id at 37-38.

34 See Akhil Reed Amar, The Bill of Rights as a Constitution, 100 Yale L J 1131 (1991).

ss 32 US 243 (1833).

39 See Amar, 100 Yale L J at 1162-75 (cited in note 34).

37 US Const, Amend II ("A well regulated Militia, being necessary to the security of a free State, the right of the people to keep and bear Arms, shall not be infringed."); US Const, Amend III ("No Soldier shall, in time of peace be quartered in any house, without the consent of the Owner, nor in time of war, but in a manner to be prescribed by law."). 
within individual states. ${ }^{38}$ Jefferson's actions spoke even louder than his words when in 1803 he knowingly betrayed his own canons of constitutional construction to purchase Louisiana from France in keeping with the geostrategy sketched out in Federalists 4 through $8 .^{39}$ The Monroe Doctrine promulgated in 1823 gave further voice to this approach. ${ }^{40}$

Consider also the most important and insightful nineteenthcentury commentary on the Constitution, Joseph Story's 1833 treatise:

It has been proudly said by a learned commentator on the laws of England [William Blackstone], that the royal navy of England hath ever been its greatest defence and ornament. It is its ancient and natural strength; the floating bulwark of the island; an army, from which, however strong and powerful, no danger can be apprehended to liberty. Every American citizen ought to cherish the same sentiment, as applicable to the navy of his own country. ${ }^{41}$

Finally, let us revisit Lincoln's constitutional brief against secession in his First Inaugural Address. Most twentieth-century readers tend to focus on those passages in which Lincoln elevates national majority rule over state majority rule, in perfect keeping with the logic of Federalist 10, while ignoring other, more geostrategic language:

Physically speaking, we cannot separate. We cannot remove our respective sections from each other, nor build an impassable wall between them. A husband and wife may be divorced, and go out of the presence, and beyond the reach of each other; but the different parts of our country cannot do this. They cannot but remain face to face; and intercourse, either amicable or hostile, must continue between them. Is it possi-

38 See, for example, Thomas Jefferson, Letter to James Madison (Feb 8, 1786), in Julian P. Boyd, ed, 9 The Papers of Thomas Jefferson 264-67 (Princeton, 1954); Letter to James Madison (Dec 16, 1786), 10 id at 602-06; Letter to Edward Carrington (Aug 4, 1787), 11 id at $678-80$.

s9 See Morris, ed, Great Presidential Decisions at 54-65 (cited in note 33).

10 Id at 82-99. Publius foreshadowed the Monroe Doctrine in a number of passages. See, for example, Federalist 4 (Jay), in Rossiter, ed, The Federalist Papers at 48-50 (cited in note 1); Federalist 5 (Jay), in id at 52-53; Federalist 7 (Hamilton), in id at 64-66; Federalist 16 (Hamilton), in id at 114; Federalist 18 (Madison and Hamilton), in id at 124, 127; Federalist 19 (Madison and Hamilton), in id at 130-31; Federalist 41 (Madison), in id at 258-59; Federalist 85 (Hamilton), in id at 521.

${ }^{41}$ Joseph Story, 3 Commentaries on the Constitution of the United States $\$ 1191$ at 78-79 (Hilliard, Gray, 1833) (citation omitted; emphasis added). 
ble then to make that intercourse more advantageous, or more satisfactory, after separation than before? Can aliens make treaties easier than friends can make laws? ${ }^{42}$

Once we begin to attune ourselves to geostrategy, we can hear in Lincoln's voice a whole set of implied concerns that we might otherwise miss. After secession, might not antebellum strife about which section would populate and control the resource-rich West become even bloodier and more dangerous? Would not Southern control of the mouth of the Mississippi River give it an economic stranglehold over the entire region from the Appalachians to the Rockies? Given that Northern states would no longer be bound by the Fugitive Slave Clause, would not increasing numbers of slaves flee northward? Would not Northern unwillingness to return these slaves constitute a possible casus belli? What if the South tried to staunch the outflow of slaves by blanketing the Mason-Dixon line with security forces and slave-catching patrols? Suppose the North responded by fortifying its side of the line with more soldiers? Might the Old Powers of Europe seek to "mediate" or otherwise intervene? And so on.

\section{The Modern American Experience}

It is not surprising that after a century of marginalization, ${ }^{43}$ Federalist 10 was rediscovered and made central to our understanding of the Constitution. After the adoption and gradual judicial invigoration of the Fourteenth Amendment, who could miss the important constitutional principle of federal protection of local minorities against their own state governments? And had not the Civil War itself-understood ex post as a War Against Slavery, rather than ex ante as a War For (Geographic) Union-shown the national government to be the last, best hope of domestic liberty, as Federalist 10 had prophesied?

What is remarkable, however, is the deep obscurity into which Publius's earlier geostrategic vision has fallen, at least in law

42 Basler, ed, 4 The Collected Works of Abraham Lincoln at 269 (cited in note 2) (emphasis in original).

43 Douglass Adair has written that

it was not until 1913, 125 years [after its initial publication], that Charles A. Beard made this particular essay famous for students of the United States Constitution. Before [1913], practically no commentator on The Federalist or the Constitution, none of the biographers of Madison, had emphasized Federalist 10 as of special importance for understanding our 'more perfect union'.... .

Adair, Fame and the Founding Fathers at 75-76 (cited in note 8). 
schools. For the issues raised by Federalists 4 through 8 and 41 have hardly disappeared, even though military technology has changed drastically (especially with the advent of air power). Consider only three examples from the last half-century. First, had the Pacific "moat" not been so wide, bombs might have fallen on the mainland rather than on Pearl Harbor. The United States in World War II was unique among the Great Powers in having virtually no destruction occur on its own soil. Second, the Cuban Missile Crisis once again illustrated the unique status of the United States in keeping hostile land-based missiles out of our hemisphere. The Monroe Doctrine was alive and well in 1962. Third, Star Wars technology in the 1980s and 1990s again illustrates America's unique geostrategic position. The system only makes sense-that is, if it makes sense at all-because land-based missiles aimed at United States targets must travel across the Atlantic and Pacific Oceans. Europeans are understandably less enthusiastic, for SDI offers them relatively little security so long as missiles remain throughout Europe, East and West. ${ }^{44}$

Why has twentieth-century constitutional scholarship tended to ignore Publius's geostrategic vision? ${ }^{45}$ In part, perhaps, it is because we may now think that the vision reflects imperialistic, if not genocidal, attitudes towards Native Americans in the West. The Monroe Doctrine may share more than initials with the American idea of Manifest Destiny that took shape in the nineteenth century. Perhaps modern-day discomfort and guilt among mainstream constitutional theorists has led them to avert their eyes from geostrategic imperialism, just as they have downplayed the role of slavery at the Founding. ${ }^{46}$

Another possible explanation for the marginalization of Publius's geostrategic vision is that it is less than obvious in the text of the Constitution. Yet it is there. Article I, $\S 10$ prevents states from keeping troops or ships of war without congressional consent, and $\S 8$ prevents Congress from making long-term appropriations

14 The issue of submarine-based missiles raises complexities far beyond the scope of my analysis here.

46 The work of my colleague Harold $\mathrm{Koh}$ is an important exception to this generalization. See, for example, Harold Koh, The National Security Constitution 77 (Yale, 1990) ("The birth of the National Security Constitution did not occur within a geopolitical vacuum. America's geographical separation from the rest of the world [has] figured ... prominently in the development of America's constitutional traditions."). See generally id at 67100.

46 For an excellent discussion of the importance of slavery at Philadelphia, see Raymond T. Diamond, No Call to Glory: Thurgood Marshall's Thesis on the Intent of a ProSlavery Constitution, 42 Vand L Rev 93 (1989). 
for the army, but not the navy. As I have already noted, the suspicion against armies in the Second Amendment has no anti-navy counterpart, and the Third Amendment's language about "soldiers" and not "sailors" reflects the prevailing Blackstonian orthodoxy that land forces posed a special threat to domestic liberty.

Despite all this, the geostrategic vision is undoubtedly less central in constitutional case law than are principles like separa-tion of powers, judicial review, freedom of speech and of the press, and due process. Traditional American lawyers are perhaps too quick to attribute America's success over the last two centuries to these doctrines simply because they are more justiciable. ${ }^{47}$

Nonlawyers, by contrast, at times argue that America's success has had virtually nothing to do with its lawyers or its Constitution, and everything to do with nonlegal factors-fertile land, navigable waterways, good climate, and natural moats creating extraordinary "peace dividends" for much of its history. Yet this argument also oversimplifies. In England and Switzerland, geographic insulation may have seemed natural and God-given, ${ }^{48}$ but in America it was self-consciously chosen. For Americans, the Atlantic Ocean is a political and not a natural moat. It became an effective moat only because lawyers like Jay, Madison, Hamilton, and Wilson structured a continental legal structure that could make it so. The Mississippi River is today a bond of economic friendship rather than a bone of military contention because a lawyer named Lincoln held together a legal Union.

47 This is not to say that the geostrategic vision would never be relevant to judges deciding cases. For example, the Insular Cases decided at the turn of the century were at the time understood as raising perhaps the biggest constitutional question of the era: whether, and how, the Constitution applied to various newly-acquired territories. The Court's ultimate approach-distinguishing "distant ocean" communities from more contiguous territories (Balzac v Porto Rico, 258 US 298, 311 (1922))-is an interesting variation on Publius's first argument. The Insular Cases have recently been the subject of two excellent studies, neither of which, alas, analyzes them through the lens of Federalists 4 through 8 . See Gary Lawson, Territorial Governments and the Limits of Formalism, 78 Cal L Rev 853 (1990); Gerald L. Neuman, Whose Constitution?, 100 Yale L J 909 (1991).

48 This argument also oversimplifies in the case of England. The mother country's insular condition was achieved only through a self-conscious political union between Scotland and England in 1707. Jay pointedly quoted the legislative history of this union, describing it as effecting "[a]n entire and perfect union" that would enable the "whole island" to better resist its foreign enemies. Federalist 5 (Jay), in Rossiter, ed, The Federalist Papers at 50 (cited in note 1). Jay here was clearly suggesting that the Philadelphia Constitution proposed a similar "more perfect union" for similar reasons. Like the union of Scotland and England, this union, once effected, was to be immune from unilateral secession. See generally Akhil Reed Amar, Of Sovereignty and Federalism, 96 Yale L J 1425, 1451-66 (1987). 
I propose, then, that serious students of our Constitution adopt a more unified perspective. Economists, generals, and social historians need to appreciate legal structure, and constitutional lawyers need to widen their own field of vision symmetrically. We need to recall that Chief Justice Jay was also Ambassador Jay, and that Hamilton was a brilliant general and military strategist as well as a first-rate trial lawyer and political theorist. Nor should we ignore George Washington's constitutional ethos simply because he lacked Hamilton's and Madison's knowledge of Hume and Montesquieu.

\section{Lessons for Europeans}

So much, then, for twentieth-century lessons for those west of the Atlantic. What is the message in all of this for Europeans today?

The key point is this: the success of democracy in individual countries depends heavily on demilitarization of the entire region. Let us briefly recall some basic facts that every schoolchild in Europe learns. Apart from the Alps and Pyrenees, few natural geographic obstacles to invasion stand between the Urals and the Atlantic. A man-made substitute for the Alps-the Maginot Lineproved useless in World War II. (The real Alps, by contrast, enabled Switzerland to escape occupation in each World War. ${ }^{49}$ ) France and Germany have fought three wars against each other since Napoleon. Mother Russia was invaded in both world wars, and of course will never forget Napoleon either. England survived the Nazi nightmare largely because of the slender sleeve of the English Channel. Western capitalist nations are not inherently immune from the totalitarianism of a Mussolini or a Hitler, or from the massive destruction of total war-and the two scourges are often related, as the 1930s and 1940s made clear.

Now consider the extraordinary success of NATO. I am not referring to the containment of communist expansion to Eastern Europe, the ostensible purpose of the alliance. Rather, I am referring to pacific relations within the alliance-the containment of military adventurism (or to be more precise, intra-European military adventurism) among member nations. Member nations point their armaments outwards, not at each other. NATO has served well a function similar to that of the United States government and the United States Constitution as envisioned by Publius's first argument.

40 Publius would not have been surprised. See note 19 . 
But the map of Europe has changed dramatically. The Wall has fallen in Germany, and cannot be replaced by a wall around Germany. Some legal structure, such as NATO, is needed now more than ever to reassure Germany's neighbors (France, Poland, and ultimately, the Soviet Union) that their soil will never again be invaded by Germany or any other nation. Interestingly, one of the final hurdles to German unification was Poland's insistence on a formal commitment that the newly enlarged Germany would respect Poland's contemporary borders. ${ }^{50}$ Poland's fears illustrate that ancient military risks are believed to persist on the continent today. And while the Kohl regime's willingness to calm those fears is admirable, any government is more likely to break such a commitment in the absence of collective security agreements.

To be sure, military technology has changed dramatically in recent years, especially with the advent of long-range missiles and smart bombs, but most wars are still fought between geographic neighbors and at great risk to civilian populations. Some regional mechanism is therefore needed to maintain a peaceful neighborhood in central Europe..$^{\text {s1 }}$

Yet even if this much were achieved by keeping a unified Germany within NATO or through some other legal structure, Eastern Europe's geostrategic posture would remain wholly different from that of the United States. There is of course no moat between the NATO countries and those to the east. To follow fully the New World example, the Old World needs to develop transnational legal structures to demilitarize the entire continent, East as well as West. The elimination of missiles would of course be much desired by those who hate war and massive destruction. But for those who hate tyranny, the dismantling of tanks and armies is perhaps even more important. These can all too easily be used domestically to crush the citizenry, as the inhabitants of Budapest, Prague, and Vilnius know all too well.

so See Thomas L. Friedman, Evolution in Europe: 2 Germanies Vow to Retain Border with the Poles, NY Times AI (July 18, 1990); Karl Kaiser, Germany's Unification, 70 Foreign Affairs 179 (1990).

$\$ 1$ A vigorous debate about the proper form of collective security arrangements for the new Europe is now underway, with numerous voices suggesting an enhanced role for the Conference on Security and Cooperation in Europe. See, for example, Robert E. Hunter, The Future of European Security, 13 Wash Q 55 (1990). My point here is not to advocate greater use of the CSCE or any other particular structure, but to suggest that the American constitutional analogy provides a powerful argument in favor of such arrangements in general. 
NATO has not been the only transnational structure in the post-war era helping to preserve peace among western European nations. The European Economic Community, the Common Market, has also played a key role in facilitating economic cooperation and coordination. The idea of free trade within the European Continent can be understood as an Old World adaptation of the New World constitutional idea of intracontinental free trade embodied in the dormant commerce clause. ${ }^{.2}$

Indeed, The Federalist Papers illustrate how economic cooperation and demilitarization went hand in hand under the Federalist Constitution. In Federalists 4 and 6, Publius noted that perceptions of unfair trading practices were among the classic causes of war. ${ }^{53}$ Free and fair trade, by contrast, would redirect citizens' energies into commercial intercourse that would strengthen ties among Americans from different regions. ${ }^{54}$ Free trade would also encourage a domestic shipping industry and make America a "nursery of seamen," argued Publius. ${ }^{.5}$ In time of war, America's commercial fleet could be converted into an American navy through letters of marque and reprisal..$^{56}$ And the synergy worked in both directions; an incipient navy would be indispensable in protecting America's commercial navigation from European and piratical attack. "[B]y a kind of reaction, mutually beneficial," navies and commercial navigation "promote each other." expanding the geographic sphere of government by bringing 13 nations under a single continental umbrella would reduce the total amount of money needed for military defense and thereby help promote the economy. Just as Federalist 10 argued that there were certain economies of scale in representative government, so too Federalists 4 through 8 argued that economies of scale existed in military affairs. The geostrategic point can almost be recast into a geometric point: defense expenditures often correlate with the

${ }^{82}$ US Const, Art I, $\S 8, \mathrm{cl} 3$ (by its terms, empowering Congress to regulate interstate commerce; commonly interpreted to also forbid state regulations that excessively burden interstate commerce). I am using the dormant commerce clause here merely as shorthand for the intricate network of constitutional provisions promoting economic cooperation and coordination among states.

${ }^{53}$ Federalist 4 (Jay), in Rossiter, ed, The Federalist Papers at 46-47 (cited in note 1); Federalist 6 (Hamilton), in id at 54.

54 See, for example, Federalist 53 (Madison), in id at 334; see generally Martin Diamond, The Federalist's View of Federalism, in Essays on Federalism 21, 49-51 (Institute for Studies on Federalism, 1961); Wills, Explaining America at 67-78 (cited in note 8).

ss Federalist 11 (Hamilton), in Rossiter, ed, The Federalist Papers at 88-89 (cited in note 1). The "nursery" image is from Federalist 4 (Jay), in id at 48.

Bs US Const, Art I, \& 8, cl 11.

${ }^{87}$ Federalist 11 (Hamilton), in Rossiter, ed, The Federalist Papers at 89 (cited in note 1). 
length of a border (perimeter) that must be defended. A larger area has, ceteris paribus, a lower perimeter-to-area ratio. To put the point another way, the need to spend money to guard intracontinental borders between states is largely eliminated by union.

The key point for Europeans today is that internal constitutional reform is not enough. Continental legal institutions like the EEC and NATO must be developed or expanded to create a continental environment conducive to commerce and demilitarization.

\section{Federalism}

The EEC and NATO offer Europeans one model analogous to the Founding of the United States Constitution-a model in which formerly distinct nation-states combine to create continental legal structures to restrain military adventurism and promote economic cooperation. For the relatively small former Soviet satellites in Eastern Europe, these models merit careful study. For the Soviet Union itself, however, the procedural and geostrategic posture is somewhat different. In the Soviet case, a legal structure spanning a continent-indeed, a continent and a half-already exists. The question is not whether the Soviets should create continental legal structures, but how much autonomy the Soviets should allow to the individual republics that comprise the union. Similar concerns apply to Yugoslavia and Czechoslovakia, the two Eastern European nations with federal systems; both are experiencing severe pressures from subunits, at least some of which prefer independence.

The geostrategic argument rehearsed thus far does not seem fully responsive to these issues. In Federalists 4 through 8 , Publius gives reasons for creating a Union, but what are his arguments for preserving states as independent entities, rather than simply abandoning them? In other words, why in Federalist 9 does Publius label himself a Federalist-one who favors retaining states-rather than a pure Nationalist ${ }^{58}$ And do any of Publius's arguments help us understand how the Soviet Union, Czechoslovakia, and Yugoslavia should structure their federal-state relations today?

\footnotetext{
ss Publius and other supporters of the Constitution may well have appropriated the Federalist label for rhetorical and political advantage. See Amar, 96 Yale L J at 1426 \& n 9 (cited in note 48). Nevertheless, Publius was emphatically a Federalist in the sense of "one who favors retaining states," which is of course the sense in which Publius himself invokes the Federalist label. See Federalist 9 (Hamilton), in Rossiter, ed, The Federalist Papers at 76 (cited in note 1) (defining federal system as one in which "separate organization of the members be not abolished"); Federalist 10 (Madison), in id at 84 (closing essay with selfdescription of Publius as a "federalist[]").
} 
As with separation of powers, the key value of federalism for Publius is that government officials guard against each other's excesses and thereby protect the liberty of ordinary citizens. Central officials-can protect citizens against state governments whenever the states become tyrannical. State officials can return the compliment when the central government oversteps its constitutional bounds. The key to this dynamic is that each government must retain a certain degree of institutional autonomy-a measure of structural independence-from the other.

We must not confuse federalism, as thus defined, with decentralization. ${ }^{69}$ Many of the common cliches about the benefits of "federalism" actually have little to do with the idea of federalism, strictly speaking. States can indeed "experiment" by passing different laws whose results can be monitored and assessed. But a centralized government could run the same kind of experiments among geographically defined "provinces" whose governments hold office at the pleasure of the center. Indeed, if experimentation is our chief desideratum, a purely pyramidic government structure may well be preferable, enabling central planners to shape and reshape government boundaries and policies for more carefully controlled experiments. Next, consider the idea that cultural, linguistic, geographic, economic, political, and other types of diversity may require different legal rules for different regions, at least on some issues. A nonfederal system can often accommodate this diversity; central officials can simply commit certain decisions to regional and local deputies. Similarly, federal systems are not the only ones that enable individuals to select their preferred set of laws by "voting with their feet." 60

The best argument for federalism, then, is neither experimentation, nor diversity, nor residential self-selection, but protection against abusive government. Just as competition among firms protects consumers from monopolistic exploitation, and competition among political parties protects voters from the insensitivity and oppression characteristic of one-party regimes, so too a healthy competition between federal and local officials can help protect cit-

s9 In an otherwise helpful discussion of federalism, Professor McConnell fails to distinguish sharply between these two concepts. Michael W. McConnell, Federalism: Evaluating the Founders' Design, 54 U Chi L Rev 1484 (1987) (review of Raoul Berger, Federalism: The Founders' Design (Oklahoma, 1987)). For a useful corrective, see Andrzej Rapaczynski, From Sovereignty to Process: The Jurisprudence of Federalism After Garcia, 1985 S Ct Rev 341, 390, 408-14.

${ }^{\circ 0}$ Compare Charles M. Tiebout, A Pure Theory of Local Expenditures, $64 \mathrm{~J}$ Pol Econ 416 (1956). 
izens against government tyranny ${ }^{61}$ Elsewhere, I have tried to offer a detailed explanation of how the federalist dynamic built into the United States Constitution works to protect liberty. ${ }^{62}$ I shall therefore only summarize my findings here, with particular emphasis on those aspects most appropriate for, and appropriable by, Eastern Europe and the Soviet Union today.

\section{A. The "Legal Check" of Federalism}

First, American federalism encompasses a legal and remedial dimension. A written constitution proclaiming itself the supreme law needs some mechanisms of legal enforcement. Judicial review is probably the best known of these mechanisms, but not the only one; it is simply one part of a larger system of separation of powers in which each branch of the national government can typically thwart a national law it deems unconstitutional-especially in the area of criminal law, where persons' lives, liberty, and property are most vulnerable. If either the House or the Senate finds a criminal bill unconstitutional-even for reasons that might not persuade judges-the bill cannot become law. And the federal courts cannot convict a person in the absence of such a law, because there is no such thing as a "federal common law" of crimes. If, in the exercise of his independent judgment and regardless of case law, the President thinks the bill unconstitutional, he may veto or pardon (even before indictment). The structure of separation of powers thus protects constitutional values by providing three separate, overlapping, and mutually reinforcing remedies-legislative, executive, and judicial-against arguably unconstitutional federal conduct.

\footnotetext{
61 So too, competition between institutions of church and state can promote liberty. When both religious and secular authority are monopolized by the same entity, tyranny is much more likely. Soviet absolutism after the revolution flowed rather naturally from Russion absolutism under the czars, with Communist Atheism replacing Christianity as the Offcial State Religion, and the Communist Party replacing the Church as the Official State Institution for Correct Thinking. To put the point another way, in Western Europe, liberty over the last thousand years benefited from various modes of competition between King and Pope for their subjects' allegiance; in the old Russian Empire, liberty suffered under czars who claimed both roles.

Recent events only further confirm the basic point. The avalanche in Eastern Europe in the 1980s might well not have occurred without the stone of Poland. But the Polish Revolution would not have been possible without Walesa and Solidarity-who in turn would not have been possible without the support of a Polish Pope and a strong Polish Catholic Church. John Paul II-who lives in the West, but grew up in the East-is truly one of the unsung heroes of the European Revolution.

${ }^{62}$ See generally Amar, 96 Yale L J at 1492-1519 (cited in note 48).
} 
A similar mechanism of overlapping protection from legal wrongs operates in the structure of federalism. If a state government violates a citizen's constitutional rights, the victim need not depend solely on whatever remedies the state provides; she can also invoke remedies furnished by the federal government, structurally independent of the wrongdoing regime. Section 1983 is the best example of this. ${ }^{63}$ Conversely, when federal officials violate the Constitution, the victim can once again often invoke remedial law furnished by a structurally independent government-here, the state. For example, prior to the Supreme Court's decision in Bivens $v$ Six Unknown Named Agents of Federal Bureau of Narcotics, ${ }^{64}$ victims seeking damages for federal Fourth Amendment violations relied almost exclusively on state trespass law. Moreover, the Seventh Amendment allows local juries, which also enjoy structural independence from the wrongdoing government, to hear these damages actions. As Alexis de Tocqueville argued at length, juries can benefit not only the aggrieved citizens who bring cases before them, but also the citizens who serve on them, offering them a chance to participate in government and to learn democracy by doing democracy. ${ }^{65}$ In one form or another, the jury system of lay participation is therefore doubly deserving of adoption/adaption in Eastern Europe. ${ }^{\text {B }}$

os 42 USC $\S 1983$ (1988) ("Every person who, under color of [state law] subjects, or causes to be subjected, any citizen of the United States or other person within the jurisdiction thereof to the deprivation of any rights, privileges, or immunities secured by the Constitution and laws, shall be liable to the party injured in an action at law, suit in equity, or other proper proceeding for redress.") This statute is now, of course, the principal legal tool for enforcement of constitutional rights by individual litigants.

os 403 US 388 (1971).

Bs Alexis de Tocqueville, I Democracy in America 280-87 (Knopf, 1963). For more discussion of the jury's role in the antebellum era, see Amar, 100 Yale L J at 1150-51, 1178-99 (cited in note 34).

68 My colleague John Langbein has thoughtfully analyzed various continental alternatives to and adaptations of the Anglo-American jury. See, for example, John H. Langbein, Mixed Court and Jury Court: Could the Continental Alternative Fill the American Need?, 1981 Am Bar Found Res J 195. Professor Langbein is less enthusiastic about the American jury system than I am, in part, I suspect, because he judges the jury primarily by its ability to serve adjudicatory values. In contrast, I follow de Tocqueville in conceptualizing the jury primarily as a "political" and not a mere "judicial" instrument-that is, as a device whose primary benefit redounds to the jurors and not the parties. See, for example, de Tocqueville, 1 Democracy in America at 285 (cited in note 65) (Jury is a "gratuitous public school, ever open, in which every juror learns his rights. ... I do not know whether the jury is useful to those who have lawsuits, but I am certain it is highly beneficial to those who judge them; and I look upon it as one of the most efficacious means for the education of the people which society can employ."). 


\section{B. The "Military Check" of Federalism}

The above arguments presuppose the regular functioning of courts of law to remedy unconstitutional conduct. But can federalism address the worst-case scenario, in which a tyrannical government throws down the mask of legitimacy, shuts down courts of law, and attempts to rule by brute military force? Here too federalism can indeed help, and in a way analogous to the horizontal separation of powers. Just as our Constitution divided control of military power among branches of the national government to better secure against tyranny-making the President commander-inchief, but giving Congress sole power to declare war, appropriate military funds, and pass rules for the regulation of military forces-so too the document divided military power vertically between state and federal government. The Constitution authorized the central government to establish a national army, but gave state governments a special role in training the members and appointing the officers of the countervailing institution of the militia. According to Publius in Federalists 28 and 46, the national government could use its army to put down any purely local insurrection threatening the republican government of a single state; conversely, an alliance of local militias led by state governments might thwart any genuine scheme of national tyranny-much as militias organized by colonial governments had successfully resisted the British army during the Revolution. ${ }^{67}$

Like virtually all other constitutional principles, the "military check" of federalism can be abused. During the 1860 s, for example, Southern state governments resorted to their state militias even though none of the constitutional prerequisites for this ultimate form of self-help had been met. Lincoln occupied the presidency by virtue of lawful election, the people's ordinary representatives in Congress were lawfully sitting and open to hear any Southern grievances, and courts of law were open to adjudicate any claims of federal illegality. Nor could secessionists even plausibly allege that the Lincoln government had engaged in unconstitutional action. Unlike the revolutionaries of 1776, the rebels of 1861 were unable to draft any convincing Declaration of Independence "submitting" to a "candid world" "facts" documenting central tyranny. To make matters even worse, the Southern governments based their claimed right of unilateral secession on an unpersuasive reading of the Con-

67 Federalist 28 (Hamilton), in Rossiter, ed, The Federalist Papers at 181 (cited in note 1); Federalist 46 (Madison), in id at 298.300. 
stitution's underlying structure. In light of the geostrategic vision discussed above, Lincoln's arguments against unilateral secession appear considerably more plausible than Jefferson Davis's arguments on the other side. Only a national majority, not a majority of a single state or region, can lawfully dissolve the American Union. ${ }^{68}$

Despite the American experience during the Civil War, Eastern Europe and especially the Soviet Union should consider some form of military power-sharing between center and periphery. If we look only at those rare occasions when the American states have actually deployed their militias against the national army, with the Civil War as Exhibit A, we get a skewed picture of the value of the military check of federalism. The most important role of the militia is not to take the field but to deter would-be tyrants. For this purpose, large, organized state militias are probably unnecessary and even dangerous. Rather, the simple existence of small (but expandable) popular "shadow" forces organized by state governments could discourage the central government's abuse of its much larger and more professional standing army, much as a would-be monopolist must take into account not only actual competitors but shadow competitors organized to enter the market if prices rise too high.

Perhaps the finest hour of the military check occurred at one of the most delicate moments of the new nation's first constitutional crisis. After increasing political acrimony between former revolutionary comrades led to a schism within the ruling elite, the dominant group (the Federalists, led by President John Adams ${ }^{68}$ ) tried to purge political dissidents (the emerging Republican Party, championed by Vice President Thomas Jefferson) using the notorious Alien and Sedition Acts. After a bitterly fought presidential

ss See Amar, 96 Yale L J at 1455-62 \& n 162 (cited in note 48); Akhil Reed Amar, Philadelphia Revisited: Amending the Constitution Outside Article V, 55 U Chi L Rev 1043, 1053 n 28, 1062 n 69, 1076 (1988).

For a discussion of the secession issue in the context of Eastern Europe today, see Cass R. Sunstein, Constitutionalism and Secession, 58 U Chi L Rev 633 (1991). Professor Sunstein's arguments against secession draw directly on the Federalist 10 tradition: he claims that (among its many drawbacks) a constitutional right to secede will tend to exacerbate factional conflict by increasing the bargaining power of particular subunits and the ethnic or religious groups that dominate them. As I hope the discussion in the text demonstrates, one can (and should) make an equally compelling case against secession as a constitutional matter by drawing on the geostrategic vision of Federalists 4 through 8 .

os Actually, Adams's role was more ambivalent and ultimately much more judicious than the one played by High Federalists like Alexander Hamilton and Timothy Pickering. See generally Richard Hofstadter, The Idea of a Party System 102-21 (California, 1969). 
election, the Republicans emerged victorious in the electoral college, but certain quirks of voting and counting threw the issue into the hands of a Federalist-dominated House of Representatives. There was concern that Congress might try to evade its clear Article II duty ${ }^{70}$ to select between Jefferson and Aaron Burr, the two (Republican) candidates who had tied for first place in the electoral college.

Suppose Congress had voted for Adams instead, or had simply refused to vote for either Burr or Jefferson, thereby maintaining Adams in office by dint of the inertia of occupancy? These unhappy scenarios never materialized, no doubt in part because of honor among leading Federalists, but perhaps also because of the latent military check of federalism. The national army was small, and leading Republican governors made clear that any defiance of the mandates of Article II would oblige state militias to take the field to resist such blatant and lawless election-stealing. ${ }^{71}$ The growls of the state watchdogs sufficed; bites proved unnecessary. The result was a truly extraordinary spectacle-a peaceful transfer of power from one party to another, only recently its mortal enemy, in obedience to the will of the people on election day. We take all this for granted today, but such an event was virtually unprecedented in 1800. The eyes of the world were upon America, and Americans gave the world a stunning lesson in democracy.

\section{The "Political Check" of Federalism}

Federalism's role in the triumph of democracy in the election of 1800 was not limited to the latent military check evident at the end. In the years preceding the election, state governments had exemplified what I shall call the "political check" of federalism-speaking out against federal policies they deemed tyrannical and unconstitutional, and seeking to mobilize political opposition to the Adams Administration. Most dramatic were the famous Virginia and Kentucky Resolutions of 1798-99 denouncing the Alien and Sedition Acts. Criticism of a congressional statute may seem mundane in 1991; in 1798, however, anyone who criticized the Sedition Act risked criminal prosecution under it, notwithstanding the clear words of the First Amendment protecting freedom of speech and of the press. But state legislators had two advantages

70 US Const, Art II, $\S 1$, cl 3.

7x See Hofstadter, The Idea of a Party System at 109, 111, $131 \mathrm{n} 10$ (cited in note 69); Dumas Malone, 4 Jefferson and His Time 6-11 (Little, Brown, 1970). 
over ordinary citizens or newspaper publishers. First, they could invoke a long tradition of absolute "freedom of speech and debate" in legislative chambers from executive or judicial interference. ${ }^{72}$ Second, in addition to the old separation of powers principle, legislators in Virginia and Kentucky could use new institutions of federalism to shield themselves. Any federal imprisonment of state legislators would have risked arousing state militias, whose officers the state governments had appointed (in many cases, from the ranks of state civilian officials).

Thus, state governments in $1798-99$ played a role similar to that of the institutional press or the opposition party today: monitoring the conduct of officials in power, and coordinating opposition to central policies deemed undesirable. Indeed, the strong First Amendment protection today enjoyed by the American press is in part a legacy of the success of state legislative action in 179899, as the Supreme Court implied when it invoked the Alien and Sedition Act controversy in its landmark opinion in New York Times $v$ Sullivan.$^{73}$ So too, as Richard Hofstadter has written, federalism was an indispensable midwife at the birth of the party system in America. ${ }^{74}$

This last point is an especially significant one for Eastern Europe, for a similar dynamic may well be unfolding in the Soviet Union today. Opposition groups may be able to challenge the hegemony of the Communist Party by winning control of the machinery of local governments. Moreover, states furnish opponents of national policy with an opportunity to secure actual hands-on experience running government, thereby strengthening their credibility as qualified candidates in the next set of national elections. In America, for example, two of our last three presidents (Carter and Reagan) ousted incumbents by convincing the electorate that they had been successful chief executives in their home states. The third (Bush) won in part by attacking the record of his opponent (Dukakis) as a state governor. In a nonfederal system, by contrast, most plausible candidates who would challenge an entrenched national leadership must do so from either a minority shadow government position within the national government, or a leadership position outside government, such as Lech Walesa's leadership of Solidarity. To put the point bluntly, the federal structure of the USSR may enable Soviet citizens considering alternatives to

\footnotetext{
72 See Amar, 100 Yale L J at 1151 \& nn 96-97 (cited in note 34).

73376 US 254, 273-76 (1964).

" Hofstadter, The Idea of a Party System at 103, 131, 179 (cited in note 69).
} 
Gorbachev to see whether Boris Yeltsin is truly capable of governing important affairs or is unable to run anything except his mouth.

\section{A Key Difference? Federalism and Tribalism}

There is, however, at least one major difference between federalism in the United States, and federalism in the USSR and (perhaps to a lesser degree) the rest of Eastern Europe. In America, state boundaries have rarely strongly correlated with deep ethnic, cultural, religious, and linguistic divisions. Surely, the United States contains some states today that are in important ways distinctive-for example, Hawaii and Utah-but American states seem far more assimilated than many Soviet republics and the ethnic regions of some Eastern European countries. ${ }^{75}$ Before the world wars, African Americans were far more geographically concentrated in the former slave states of the South, but at that time they were largely excluded from the polity (at first de jure, and later de facto). And at the time of the adoption of the Constitution there was some cultural, ethnic, linguistic, and religious diversity that corresponded to state boundaries. For example, one third of Pennsylvanians spoke German, and in 1794 Congress seriously considered German language statutes in Congress. ${ }^{76}$ Congregationalists dominated New England, while Pennsylvania, Maryland, and Virginia were Quaker, Catholic, and Anglican strongholds, respectively. Nevertheless, there was enough homogeneity-among whites, that is-for Jay to be able to say with a straight face in Federalist 2:

Providence has been pleased to give this one connected country to one united people-a people descended from the same ancestors, speaking the same language, professing the same religion, attached to the same principles of government, [and] very similar in their manners and customs $\ldots .{ }^{77}$

Full exploration of the United States experience in federalism in cases where ethnic or religous differences have loomed large-consider, once again, Hawaii and Utah, or the American Bantustans called Indian Reservations ${ }^{78}$-is beyond the scope of

${ }^{76}$ For more discussion, see Sunstein, $58 \mathrm{U}$ Chi L Rev at 643-47 (cited in note 68).

${ }^{76}$ Warren, The Supreme Court and the Sovereign States at 10 (cited in note 32).

${ }^{77}$ Federalist 2 (Jay), in Rossiter, ed, The Federalist Papers at 38 (cited in note 1).

78 Professor Judith Resnik has recently offered a very thoughtful essay on the ways in which the Native American experience can help to deepen-and render problematic-our 
this essay. Even without a detailed study, though, it is clear that American federalism has not been unproblematic when the premise of Federalist 2 has been wholly lacking. Perhaps the best-if sobering-New World lessons for the Old World on this topic may come from America's neighbor to the north, Canada.

\section{Civilian Supremacy}

Military subordination to rules established by civilian officials is a principle that Americans take for granted today. The Founders enjoyed no such luxury. Popular histories of classical antiquity were filled with examples of military men such as Darius and Caesar wresting sceptres for themselves, and recent English history gave little cause for optimism. Had not Cromwell used his army to establish himself as Lord Protector? Nor did the American Revolution appear at some magical endpoint of the era of military coups. Less than a decade after former revolutionary General Washington peacefully, even eagerly, relinquished his position as American president and commander-in-chief, former revolutionary General Bonaparte proclaimed himself emperor in Paris. Even today, one regularly hears serious discussion about whether the Soviet Army leadership will accept the changes being orchestrated by the political leadership, or will instead attempt to take matters into its own hands.

In America, however, such discussions have been much less frequent and serious over the last 200 years. America's geostrategic position deserves some of the credit. Until its emergence as a global superpower after World War II, the United States got by with only a small standing army in peacetime-a happy situation made possible by America's unique geographic isolation from the Old Powers of Europe and their militaries. The smaller the domestic army, the less the threat of a coup. The military check of federalism may also have contributed to the impressive record of restraint compiled by American generals. As noted earlier, the most important function of the militia is to deter army adventurism by lowering the odds of its success.

But what accounts for civilian supremacy in America today, when we do have a sizable national standing army and when it would be fanciful to argue that independent state militias counter-

understandings of words like "federalism" and "sovereignty" in American constitutional discourse. See Judith Resnik, Dependent Sovereigns: Indian Tribes, States, and the Federal Courts, 56 U Chi L Rev 671 (1989). 
poise it? The constitutional text ${ }^{79}$ provides an obvious but only partial explanation. Tradition also seems to loom large here. It is nothing new to suggest that human beings are largely creatures of habit. Hamilton, for example, listed "the habitual sense of obligation" as one of the five most important explanations of obedience to authority in his most extended speech at the Philadelphia convention. ${ }^{80}$ And nowhere is habit more self-consciously cultivated than in the military, where soldiers are drilled and redrilled until they perform tasks by rote. Nor is any habit more cultivated in the military than that of near-reflexive obedience to one's duly constituted superiors.

Indeed, the force of habit explains why soldiers with guns are so much more dangerous to fellow citizens than policemen with guns. Police are trained to deal with ordinary civilians, to calm disputants, to cool heated arguments, to use discretion and situation sense. Soldiers, by contrast, are trained to destroy a disciplined enemy, to obey orders unthinkingly, to shoot on command, and to shoot to kill. And when soldiers are used domestically as police substitutes, and brought face to face with fellow citizens rather than enemy soldiers, tragedy can result-from the Boston Massacre in 1770 to Kent State exactly 200 years later, ${ }^{\mathbf{8 1}}$ from Tiananmen to Timisoara.

In America, the military's tradition of almost-blind obedience has always encompassed as a first principle that the highest duly constituted authority is a civilian commander-in-chief selected by peaceful political means without the flexing of military muscle. But how did this tradition establish itself in America? In much of the world, after all, the military "tradition" is just the opposite. The idea of a coup is hardly unthinkable, and once thought leads to successful action, it is hard to put the genie back in the bottle; one good coup deserves another. Yet America has never had such a military putsch. Even in the Civil War, the issue was ultimately one of which set of civilian officials and which civilian electorate-state or national-was indeed constitutionally supreme. Military men like Robert E. Lee followed political leaders like Jefferson Davis, not the reverse.

70 See, for example, US Const, Art I, $\S 8, \mathrm{cl} 11-15$ (vesting in Congress the powers to declare war, to maintain and govern the army and navy, and to call up the militia in time of insurrection or invasion), and US Const, Art II, $\S 2, \mathrm{cl} 1$ (making the president commanderin-chief).

${ }^{80}$ Farrand, ed, 1 The Records of the Federal Convention of 1787 at 305 (cited in note 28).

-1 See David E. Engdahl, Soldiers, Riots, and Revolution: The Law and History of Military Troops in Civil Disorders, 57 Iowa L Rev 1 (1971). 
Perhaps a different tradition might have taken root in late eighteenth-century America had it not been for George Washington. In 1783, several of Washington's officers appear to have been planning a military takeover of power from the incompetent Congress then trying to govern under the weak Articles of Confederation. ${ }^{82}$ But upon learning of the plot, Washington would have no part of it. He chose the role not of Caesar or Cromwell, but of Cincinnatus, the famous Roman soldier who left his plow to become a general and save his city, but who quickly surrendered his uniform after the fighting ended and returned to his farm.

The details of Washington's conduct during the so-called Newburgh Affair of 1783 may not have been widely known in the late $1780 \mathrm{~s}$, but Washington's commitment to civilian supremacy was legendary. America's first president was indeed a general, but as president he made clear that his civilian role predominated. $\mathrm{He}$ even dressed the part, for as president, Washington wore civilian clothes, not a military uniform. He offers a marked contrast to three men of our era who, like Washington, graduated from revolutionary generalships to become chief executives of newly founded regimes: Franco, Mao, and Castro. Washington's self-conscious dress was not simply a reflection of military inability brought on by age; as president, Washington personally took the field to lead federal troops in putting down the Whiskey Rebellion of $1794 .^{83}$ Rather, Washington self-consciously tried to teach his country and the world a lesson about civilian supremacy. He may not have had a way with words, but his actions-and even his garb-spoke volumes.

Exemplified by men like Washington and Robert E. Lee, commander of the Confederate forces in the Civil War, this tradition of civilian supremacy lives on today among the American military. The ethos is given institutional form in military schools like West Point and Annapolis, and the Virginia school for civilians named after the two generals noted above. Just as a legal ethic of judicial review, judicial restraint, and the rule of law is institutionalized in stories about John Marshall told in today's law schools (including one that bears his name), so too an ethic of civilian supremacy draws importantly on didactic narratives about men like George

\footnotetext{
${ }^{82}$ For accounts of this event, see Merrill Jensen, The New Nation 69-72 (Knopf, 1950); Garry Wills, Cincinnatus: George Washington and the Enlightenment 5-9 (Doubleday, 1984).

Bs See Morris, ed, Great Presidential Decisions at 22-28 (cited in note 33).
} 
Washington. And these narratives are not merely relics of the nineteenth century. When a general openly challenges civilian authority, as Douglas MacArthur challenged Truman after World War II, it may irreparably damage his reputation, even if the challenge falls far short of a coup. There are, to my knowledge, no American military schools or colleges named after MacArthur.

How can comparable traditions be established or strengthened in Eastern Europe? As in the American experience, constitutional texts provide an appropriate starting point. There is at least some cause for optimism on this score; several of the constitutions recently adopted or now under discussion in Eastern Europe specifically forbid military intervention in domestic affairs without the express authorization of parliament or the chief executive. ${ }^{84}$ Again, though, it is worth emphasizing that the text alone is a mere parchment barrier. The regional demilitarization suggested earlier will of course help by shrinking the size of the Eastern European military machines. So too, the strengthening of democratic political procedures may prove critical; arguably, the more legitimate and popular the military perceives the civilian leadership to be, the higher the perceived cost of attempting a coup. If Gorbachev had a direct mandate from the Soviet electorate, might not his position vis-à-vis the military be that much more secure?

Finally, serious attention must be paid to the institutions of military training. Some of the issues here are structural. For example, the United States has deployed "competition" among military schools, leading to a type of "separation of powers" among the military services-army, navy, air force, and marines. This separation is widely thought to have diminished the efficiency of American military planning, particularly in matters like procurement and weapons development. But we have tolerated whatever inefficiencies may have resulted in part because the separation also discourages democracy-threatening cabal and intrigue. Other issues are more pedagogic. How can military academies best teach and internalize the principles of democracy and civilian supremacy?

\footnotetext{
st See, for example, the new Hungarian Constitution, Art 19, § 3(j) (on file with U Chi L Rev) (Parliament decides on use of armed forces "inside or outside the country"). See also Romanian Parliament Committee for Drafting the Constitution of Romania, Theses for the Draft Constitution of Romania 6, Title I, § 13 (ROMPRES National News Agency, 1990) (on file with U Chi L Rev) (proposing that military may be used internally "in defence of the Constitutional order and the protection of the fundamental civil rights and liberties," but only when "explicitly provided for by law," "for a limited time and with a pre-set purpose," and with the authorization of the Supreme Council of National Defence, a body under the parliament's control).
} 


\section{CoNCLUSION}

Publius and Lincoln were right. The American experiment in self-rule does indeed yield important lessons for all humankind in search of a more free, a more democratic, a more peaceful, and a more prosperous world. Some of these New World lessons, such as the importance of federalism and jury trial, can perhaps be deduced by a simple reading of the Constitution itself. Other lessons are more subtle, for they radiate far beyond the four corners of the document. For example, we need to understand how international and geostrategic concerns affect the domestic legal order, and how unwritten traditions and precedents established at or near the founding may prove even more powerful than a constitution's naked text. The establishment of new constitutions in individual Eastern European countries can only set the stage. The second act of the drama must involve the development of continental legal structures and stable domestic traditions of mutual tolerance, and executive and military self-restraint.

The words of Federalist 1, with which I began this essay, appeared in New York newspapers on October 27, 1787.85 Five days earlier, Benjamin Franklin-a framer who had spent considerable time in both the Old and the New Worlds-sent a letter to a European friend that also alluded to the global implications of the proposed American Constitution. Modern-day Europeans would do well to ponder Franklin's evocative words:

If [our Constitution] succeeds, I do not see why you might not in Europe carry the project of good Henry the 4th into execution, by forming a Federal Union and One Grand Republic of all its different states and kingdom[s] by means of a like Convention. ${ }^{86}$

\footnotetext{
ss See Rossiter, ed, The Federalist Papers at viii (cited in note 1) (editor's introduction).

${ }^{83}$ Benjamin Franklin, Letter to M. Grand (Oct 22, 1787), quoted in Warren, The Supreme Court and the Sovereign States at 145-46 n 41 (cited in note 32).
} 